\title{
Dziąalność NAUKOWA I DYDAKTYCZNA Profesor Aleksandry Jewtuchowicz
}

\section{CZTERDZIEŚCI LAT PRACY NA UNIWERSYTECIE ŁóDZKIM}

W 2013 r. mija 40 lat pracy prof. Aleksandry Jewtuchowicz w Uniwersytecie Łódzkim. Jest to dobra okazja, aby przedstawić ścieżke Jej kariery zawodowej i podsumować dorobek naukowy, dydaktyczny i organizacyjny.

\section{Ukończenie studiów i pierwsza praca}

Prof. Aleksandra Jewtuchowicz ukończyła studia w 1969 r. na Wydziale Ekonomiczno-Socjologicznym Uniwersytetu Łódzkiego ze specjalnościa Ekonomiki Przemysłu. Jej praca magisterska pt. Problemy fluktuacji sity roboczej w przedsiębiorstwach województwa tódzkiego została napisana pod kierunkiem prof. dr hab. Władysława Piotrowskiego. Po studiach podjęła swoja pierwsza prace w Wojewódzkiej Komisji Planowania Gospodarczego w Łodzi. Zajmując się tam zagadnieniami koordynacji i lokalizacji inwestycji, zainteresowała się problematyka gospodarki regionalnej. Zdobyte podczas tych prac doświadczenia wpłynęły na Jej decyzję pogłębienia wiedzy teoretycznej. W efekcie, w latach 1972-1975 rozpoczęła Podyplomowe Studia Urbanistyki i Inwestycji Miejskich. Studia te miały dwie specjalizacje: urbanistykę i inwestycje miejskie. Pierwsza była prowadzona przez prof. dr hab. Jerzego Regulskiego, druga przez prof. Zdzisława Prochowskiego. Wybór urbanistyki i kontakt z prof. dr hab. J. Regulskim zadecydowały o Jej przyszłej karierze zawodowej.

W 1973 r. podjęła decyzje o powrocie na Uniwersytet Łódzki. Zostaje, zgodnie z ukończona specjalnością, asystentem w Zakładzie Ekonomiki Przemysłu Instytutu Ekonomiki Produkcji, kierowanym przez 
Jej pierwszego promotora prof. dr hab. Władysława Piotrowskiego. Od pierwszego dnia Jej opiekunem staje się dr Jadwiga Niedomagała, która wprowadzała Ja w tajniki pracy dydaktycznej i naukowej.

\section{Praca na Uniwersytecie Łódzkim i udział w powstawaniu lódzkiej szkoły ekonomiki miast i regionów}

W 1974 r. prof. dr hab. J. Regulski otwiera na Uniwersytecie Łódzkim w ramach Instytutu Ekonomiki Produkcji, Zakład Rozwoju Miast. $\mathrm{Na}$ Wydziale Ekonomiczno-Socjologicznym jest to zupełnie nowa specjalizacja. W tym czasie mgr Aleksandra Jewtuchowicz kończy rozpoczęte w 1972 r. studia podyplomowe, pisząc prace zaliczeniową pod Jego kierunkiem. Szukając pracowników do swojej jednostki, Profesor proponuje Jej zatrudnienie w nowo utworzonym Zakładzie. Zmiana Zakładu staje się decyzja przełomową w Jej karierze. Od tego czasu problematyka rozwoju miast i regionów towarzyszy przez całe Jej życie zawodowe.

Prof. dr hab. J. Regulskiego należy uznać za twórcę łódzkiej szkoły ekonomiki miast i regionów, a szerzej szkoły badań przestrzennych. W 1976 r. Zakład Rozwoju Miast zmienia nazwę na Zakład Ekonomiki Rozwoju Miast, natomiast w 1978 r. Profesor J. Regulski powołuje Instytut Polityki Regionalnej, który zbiera w jednej jednostce badania przestrzenne, rozproszone do tej pory w różnych zakładach i katedrach Wydziału.

Pozycja w świecie naukowym prof. dr hab. Jerzego Regulskiego, Jego bogata wiedza, nowatorski styl pracy i osobowość zadecydowały o profilu badawczym pracowników Zakładu, w tym, także prof. Aleksandry Jewtuchowicz. W pierwszym okresie Jej zainteresowania naukowe skupiały się głównie na zagadnieniach związanych z miastami i organizacją systemów osadniczych. W badaniach tych wyraźnie zarysowuja się dwa nurty badawcze. Pierwszy dotyczy teorii rozwoju i funkcjonowania miast i ewolucji ich struktury wewnętrznej, drugim sa studia nad przemianami systemów osadniczych i zmianami w hierarchii miast. Zwieńczeniem Jej badań nad tymi tematami stała się napisana pod kierunkiem prof. dr hab. Jerzego Regulskiego i obroniona w 1978 r. rozprawa doktorska pt. Wptyw przedsiębiorstw przemystowych na poprawe warunków życia ludności miejskiej wybranych województw. Rozprawa ta otrzymała w 1979 r. nagrodę Ministra Nauki, Szkolnictwa Wyższego i Techniki oraz nagrodę Wojewody Piotrkowskiego. Kontynuacją Jej zainteresowań w tej dziedzinie były późniejsze analizy procesów urbanizacji, mechanizmów rządzących tymi procesami i czynników decydujacych o hierarchii miast i procesach współczesnej metropolizacji, jak 
również prace dotyczące dostosowania polskiego systemu osadniczego do procesów urbanizacyjnych obserwowanych w Europie.

Koniec lat 70 . i początek 80 . XX w. były szczególne dla Polski. Nieefektywność systemu politycznego i gospodarki centralnie planowanej zaczęła wywoływać coraz większe niezadowolenie społeczne. Protesty i związane z tym represje przyczyniły się do konsolidacji opozycji, dla której coraz wyraźniejsza stawała się konieczność reformowania systemu. Do dyskusji na ten temat włączają się różne środowiska i nieformalne grupy. Jedna z nich było, powstałe 1978 r. Konwersatorium „Doświadczenie i Przyszłość". W jego działalność zaangażowany był prof. J. Regulski, którego prace nad reaktywowaniem samorządów terytorialnych wniosły nowe impulsy i wyznaczyły nowe kierunki badawcze w Zakładzie Ekonomiki Rozwoju Miast. W 1981 r. powstał pierwszy raport Samorzadne wtadze terenowe $w$ zreformowanym ustroju gospodarczym PRL (autorstwa J. Regulskiego, P. Burego, A. Jewtuchowicz, T. Markowskiego), który zawierał tezy odbudowy samorządu terytorialnego w Polsce.

Wprowadzenie stanu wojennego zablokowało dyskusje o samorząności lokalnej w Polsce i wstrzymało prace nad jej odbudowaniem. Lata 80. XX w. to dla prof. Aleksandry Jewtuchowicz okres poszerzania wiedzy o funkcjonowaniu miast i osadnictwa oraz kontynuowanie (w miare ówczesnych możliwości) badań na temat samorządów lokalnych. W ciągu tych lat, z inicjatywy prof. Jerzego Regulskiego i pod jego kierownictwem, realizowane były też różne programy międzynarodowych badań porównawczych. Nawiązana m.in. współpraca z uniwersytetem w Nijmegen (Holandia) umożliwiła prof. Aleksandrze Jewtuchowicz odbycie w 1980 r. pierwszego zagranicznego stażu naukowego, jak i uczestnictwo w pracach grupy badawczej PONECOS (Poland-Netherlands Comparative Study).

Przełomowym pod tym względem okazał się rok 1983, w którym otrzymała Ona stypendium Rządu Francuskiego i wyjechała na 5 miesięczny staż do Uniwersytetu Paris X-Nantèrre. Będąc pod opieką wybitnego francuskiego znawcy problematyki regionalnej i miejskiej P.H. Derycke'a, miała okazję zapoznać się z literatura światowa w tym zakresie. Szczególnie zainteresowała Ja problematyka efektów zewnętrznych. W Paryżu zredagowała na ten temat swój pierwszy artykuł w języku francuskim pt. L'industrie et l'organisation spatiale en presence d'effets externes d'agglomeration dans l'économie planifiée. Został on opublikowany w Zeszytach Naukowych CERVE Uniwersytetu Paris X-Nantèrre (1983). Owocem tych studiów stał się cykl prac dotyczacych istoty efektów zewnętrznych oraz ich wpływu na funkcjonowanie systemów społecznych, za który otrzymała w 1987 r. nagrodę indywidualna trzeciego stopnia Rektora Uniwersytetu 
Łódzkiego. Tematyka ta stanowiła również kluczowe zagadnienie Jej rozprawy habilitacyjnej pt. Efekty zewnętrzne $w$ procesach urbanizacji i industrializacji obronionej w 1988 r. Stanowiła ona w Polsce jedno z nielicznych opracowań na temat teorii efektów zewnętrznych i została nagrodzona przez Rektora Uniwersytetu Łódzkiego.

Odbyte staże w krajowych i zagranicznych ośrodkach umożliwiły prof. Aleksandrze Jewtuchowicz zdobycie doświadczeń w prowadzeniu samodzielnych badań naukowych. W latach 1986-1990 kierowała dwoma tematami realizowanymi w ramach Centralnych Programów Badań Podstawowych: Bariery w gospodarczym i przestrzennym rozwoju miast i regionów oraz Rozwój regionalny - rozwój lokalny - samorzad terytorialny. Wyniki tych prac stały się podstawa do napisania szeregu artykułów naukowych i posłużyły jako materiał dla opracowania ekspertyz na potrzeby administracji wojewódzkiej i rządowej.

\section{Transformacja ustrojowa - nowe problemy, nowe szanse i wyzwania}

Zmiany polityczne, jakie nastapiły w Polsce po 1990 r. zaowocowały reorganizacją Uniwersytetu Łódzkiego i w tym Wydziału EkonomicznoSocjologicznego. W 1992 powstaja nowe jednostki organizacyjne i jednocześnie przestaje funkcjonować szereg instytutów, w tym Instytut Polityki Regionalnej. Na jego likwidacje wpłynęła m.in. rezygnacja z pracy na Uniwersytecie Łódzkim prof. dr hab. J. Regulskiego, który przyjmuje funkcje pełnomocnika ds. samorządu terytorialnego w rządzie Premiera Tadeusza Mazowieckiego. Powstaje nowa jednostka: Zakład Ekonomiki Regionalnej i Ochrony Srodowiska, utworzony na bazie pracowników Zakładu Gospodarki Przestrzennej i Pracowni Dydaktycznej. Kierownikiem Zakładu zostaje dr hab. Aleksandra Jewtuchowicz. Zakład ten w 2006 r. przekształcił się w Katedrę Gospodarki Regionalnej i Środowiska.

Zmiana sytuacji politycznej wymusiła inne spojrzenie na terytorialny rozwój gospodarczy i społeczny oraz skłoniła do poszukiwania mechanizmów właściwych gospodarce rynkowej. Zagadnienia gospodarki lokalnej, regionalizacji i szeroko pojętej polityki transformacji regionów w skali kraju i skali globalnej sa przedmiotem znakomitej większości prac prof. Aleksandry Jewtuchowicz z lat 90. XX wieku. Podstawą intelektualna tego wątku Jej prac jest, ogólnie rzecz biorąc, stwierdzenie, że przemiany we współczesnej gospodarce charakteryzują takie zjawiska jak: globalizacja i związana z tym decentralizacja władzy wiążąca się z nową logika gospodarowania, znaczenie i silny wpływ nowych technologii prowadzacy do budowania społeczeństwa opartego 
na wiedzy, powstanie nowych mechanizmów rozwoju terytorialnego i pojawienie się koncepcji regionów „uczących się”. Wszystkie te zagadnienia znajduja swoje odzwierciedlenie w publikowanych artykułach i pracach eksperckich. Była, i jest, wielokrotnie powoływana w charakterze konsultanta naukowego i eksperta (w tym eksperta dla programu PHARE) w zakresie rozwoju terytorialnego. Kierowała również zespołami badawczymi bądź uczestniczyła w opracowywaniu licznych planów strategii rozwoju oraz studium uwarunkowań i kierunków zagospodarowania przestrzennego. Współpraca z praktykami stwarzała Jej dobre warunki do weryfikacji swoich przemyśleń teoretycznych oraz do poszukiwania zarówno metod jak i mechanizmów rządzących gospodarka gmin i regionów. Swoje przemyślenia publikowała w czasopismach polskich i zagranicznych oraz prezentowała na licznych konferencjach krajowych i międzynarodowych. Z tego okresu za istotny należy uznać cykl artykułów opublikowanych w języku francuskim w Cahiers d'Economie Appliquée aux Sciences Humaines (CEASH) wydawanych przez Uniwersytet Montpellier 3. Ogólnie, Jej dorobek w tym okresie można zakwalifikować do następujacych grup problemowych:

- wpływ procesu globalizacji, metropolizacji i integracji europejskiej na rozwój regionów;

- decentralizacja władzy, wiążąca się ze studiami i badaniami nt. rozwoju lokalnego, jego specyfiki, genezy, wymiarów i skali;

- regionalne procesy restrukturyzacyjne, obejmujace prace ukazujące nową logikę gospodarowania, tworzenie się nowych przestrzeni produkcyjnych, przechodzenie do nowych koncepcji rozwoju związanych z nowymi technologiami;

- uwarunkowania powstawania innowacyjnych środowisk przedsiębiorczości; przedmiotem badań są tu mechanizmy, które uruchamiaja proces tworzenia się takiego środowiska, prowadzący $\mathrm{w}$ konsekwencji do powstawania różnych form terytorialnej organizacji produkcji,

- procesy rekonwersji regionalnej i ich charakterystyka; celem tych prac jest $\mathrm{m}$. in. porównanie przebiegu polskich procesów dostosowawczych i przyjętej polityki rozwoju z rozwiązaniami stosowanymi w krajach Europy Zachodniej.

Lata 90. to również okres tworzenia nowego Zakładu i budowanie jego spójności. Podejmowane badania krajowe i międzynarodowe oraz zaangażowanie we współprace z samorządami terytorialnymi kształtowały jego profil naukowy. Realizowane studia w ramach licznych grantów badawczych (zlecanych przez ministerstwa, jednostki samorządu terytorialnego różnego szczebla, jak również finansowanych przez środki Unii Europejskiej), pozwoliły stworzyć prof. Aleksandrze Jewtuchowicz sprawny 
i kreatywny zespół naukowców składający się z pracowników początkowo Zakładu, a później Katedry Gospodarki Regionalnej i Środowiska.

Prowadzone w Katedrze wspólne badania empiryczne i studia teoretyczne, obok Jej własnych autorskich artykułów, zaowocowały publikowanymi, pod Jej kierownictwem naukowym monografiami, z których do najistotniejszych można zaliczyć: Terytorialne i ekologiczne aspekty rozwoju gospodarcsprawzego (1997), Środowisko przedsiębiorczości, innowacje a rozwój terytorialny (1997), Strategiczne problemy rozwoju regionów $w$ procesie integracji europejskiej (2000), Struktury i procesy ksztattujace tódzki region społeczno-gospodarczy (2002, współredakcja z A. Suliborskim). Nie do przecenienia była także możliwość przeprowadzania badań na potrzeby prac związanych ze zdobywaniem tytułów i stopni naukowych.

Badania nad procesami globalizacji i związanej z tym decentralizacją władzy w sposób naturalny kieruje zainteresowania Pani Profesor na regionalne i lokalne warunki rozwoju. Przyjmujac, jako punkt wyjścia stwierdzenie, że konkurencja jest globalna a konkurencyjność buduje się lokalnie, podejmuje studia teoretyczne i badania empiryczne na temat przestrzennej organizacji lokalnych systemów produkcyjnych. Pojęciem centralnym i osią, wokół której koncentrują się Jej rozważania jest terytorium i terytorialny wymiar rozwoju. Efektem tego nurtu badawczego jest wydana w $2004 \mathrm{r}$. pod Jej redakcja naukowa praca zbiorowa Wiedza, innowacyjność, przedsiębiorczość a rozwój regionów oraz własna książka wydana w 2005 r. pt. Terytorium i wspótczesne dylematy jego rozwoju. Ta ostatnia pozycja (wraz z pozostałym dorobkiem) stała się podstawa do nadania prof. Aleksandrze Jewtuchowicz w 2006 r., przez Prezydenta Rzeczpospolitej Polski Lecha Kaczyńskiego, tytułu profesora nauk ekonomicznych.

Ksiażka ta stanowi, w dużym stopniu, synteze Jej dotychczasowych prac tak teoretycznych jak i empirycznych. Podejmuje w niej próbe uporządkowania współczesnych koncepcji rozwoju terytorialnego, pokazanie czynników, które decyduja o dynamice tego rozwoju oraz warunków włączania się lokalnych gospodarek w szybki i skomplikowany proces globalizacji. Myślą przewodnią jest analiza relacji społeczeństwo - gospodarka, co w praktyce przekłada się na relacje terytorium lokalne - przedsiębiorstwo. Zagadnieniem centralnym jest terytorium i sposób, w jaki wpływa ono na zachowania i organizacje produkcji będąc jednocześnie samo przez tę produkcję przekształcane. Za tę książkę Pani Profesor otrzymała w 2006 indywidualną nagrodę Ministra Nauki i Szkolnictwa Wyższego.

Istotna część aktywności naukowej prof. Aleksandry Jewtuchowicz stanowi uczestnictwo w konferencjach naukowych, krajowych i zagranicznych, na których - po uzyskaniu stopnia doktora habilitowanego 
- wystapiła z ponad 70 referatami (w tym wielu w języku francuskim). Większość z nich została opublikowana w recenzowanych monografiach. W dyskusjach i referatach wygłaszanych na konferencjach Pani Profesor konsekwentnie prezentuje nowe (przynajmniej w Polsce) podejścia i koncepcje rozwoju terytorialnego.

\section{Współpraca z uniwersytetami francuskimi}

Od początku swojej działalności naukowej prof. Aleksandra Jewtuchowicz rozwijała kontakty naukowe $\mathrm{z}$ uczelniami zagranicznymi, ale szczególne miejsce w Jej karierze zawodowej zajmuje współpraca z naukowcami francuskimi. Datuje się ona od początków lat osiemdziesiątych, kiedy podjęła współpracę z Instytutem Geografii Uniwersytetu Warszawskiego, której efektem było aktywne uczestnictwo w polsko-francuskiej grupie badawczej. Umowa zawarta między Uniwersytetem Warszawskim i Uniwersytetem Paul Valéry Montpellier III nazwana „Languedoc-Mazowsze” zakładała badania porównawcze na temat rozwoju lokalnego i regionalnego. Rezultatem tych badań, przeprowadzanych w latach 1982-1992 równolegle w Polsce i we Francji, były m.in. studia przypadków gmin polskich i francuskich. Stanowiły one cykl publikacji w języku francuskim, wydawany w latach 1984-1992 przez Uniwersytet Warszawski i Uniwersytet Montpellier III pod wspólnym tytułem Valeur de l'espace et développement local.

Udział w tych badaniach i staż na Uniwersytecie Paris X-Nantèrre, zapoczatkowały ścisłe kontakty naukowe Pani Profesor ze środowiskiem regionalistów frankofońskich. W 1992 r. zostaje Ona członkiem międzynarodowego frankofońskiego stowarzyszenia nauk regionalnych (Association de Science Régionale de Langue Française [ASRDLF]), w którego pracach uczestniczy do dzisiaj. Z Jej inicjatywy, ASRDLF organizuje w 1993 r. w Łodzi (wspólnie z kierowanym przez Nią Zakładem Ekonomiki Regionalnej i Ochrony Środowiska) konferencję, będąca częścia corocznego kongresu pt. Développement local $i$ régional dans la période de transformation de l'économie polonaise, na która przyjechali wybitni regionaliści z Polski i Europy.

Rezultatem uczestnictwa prof. Aleksandry Jewtuchowicz w grupie „Languedoc-Mazowsze” było zainicjowanie bezpośredniej współpracy między Uniwersytetem Paul Valéry Montpellier III i Uniwersytetem Łódzkim. Początkowo współpraca ta nie była sformalizowana, spotkania i kontakty odbywały się przy okazji konferencji i udziału w badaniach prowadzonych przez inne ośrodki naukowe. Punktem zwrotnym tych kontaktów stały się pierwsze częściowo wolne wybory z 1989 r., powołanie 
nowego rządu i przystapienie do zmian ustrojowych. Współpracujący z prof. Aleksandrą Jewtuchowicz naukowcy z Francji z ciekawością i dużym zainteresowaniem przyglądali się wysiłkom przestawienia polskiej ekonomii i polskiego społeczeństwa na tory gospodarki rynkowej. Nie tylko z politycznego, ale także z naukowego punktu widzenia był to bowiem przypadek szczególny. Polakom zaś brakowało dobrych przykładów i podstaw teoretycznych wyjaśniajacych nowe zjawiska i procesy. W 1990 roku powstała więc idea prowadzenia wspólnych studiów i badań na temat przebiegu polskiej transformacji, podczas których koledzy z Francji zapoznawali się z polską specyfiką i jednocześnie służyli wiedzą na temat mechanizmów funkcjonowania gospodarki rynkowej. Inicjatywa ta zaowocowała podpisaniem pierwszej pięcioletniej umowy o bezpośredniej współpracy między Uniwersytetem Łódzkim, reprezentowanym przez Katedrę Gospodarki Regionalnej i Środowiska (ówcześnie Zakład Ekonomiki Regionalnej i Ochrony Środowiska) Wydziału Ekonomiczno-Socjologicznego a Uniwersytetem Paul Valéry Montpellier III. Kierownikami zespołów badawczych i odpowiedzialnymi za przebieg umowy zostały: ze strony francuskiej prof. Geneviève Duché a ze strony polskiej prof. Aleksandra Jewtuchowicz.

Umowa ta, obok wymiany wykładowców oraz staży dla studentów i młodych badaczy, zakładała wspólne prowadzenie badań. Dorobek tej polsko-francuskiej grupy badawczej stanowią liczne książki, artykuły (w języku polskim i francuskim), prace niepublikowane oraz różnego rodzaju ekspertyzy wykonywane dla samorządów terytorialnych, instytucji regionalnych, itp. (bilans 20 letniej współpracy pokazuje publikacja: Terytorialny wymiar procesów innowacji i przedsiębiorczości. Studia polsko-francuskie (lnnovation et entrepreneuriat: quels enjeux territoriaux? Analyses croisées franco-polonaises), pod red. (sous la direction de) A. Jewtuchowicz, G. Duché, A. Nowakowska, C. Peyroux, Wyd. Uniwersytetu Łódzkiego, Łódź 2012). Doliczyć do tego trzeba systematycznie organizowane wspólne seminaria i konferencje. Sukces tej współpracy jest niewatpliwy. Nie do przecenienia jest jej rola w rozwoju naukowym wszystkich uczestniczących w niej osób. Dała ona szansę uczestnictwa w europejskich organizacjach naukowych i konferencjach oraz umożliwiła wchodzenie w międzynarodowe sieci badawcze. W końcu, co jest równie ważne, zaowocowała ona wieloma przyjaźniami i osobistymi kontaktami oraz pozwoliła lepiej poznać i zrozumieć inne środowiska i społeczności.

Od blisko 20 lat prof. Aleksandra Jewtuchowicz jest członkiem Komitetu Pilotażowego (rady zarządzającej) międzynarodowej sieci badawczej PGV (Un reseau de Laboratoires Europeens associant des Pays d'Europe Occidentale et des Pays du Groupe de Vysegrad), powstałej 
z inicjatywy Claude'a Martina z Uniwersytetu Pierre Mendes-France w Grenoble. Sieć ta łączy badaczy z kilkunastu krajów europejskich spotykających się corocznie na konferencjach naukowych w różnych krajach członkowskich Unii Europejskiej. Od 2010 r. sieć PGV ma status formalnego stowarzyszenia.

\section{Kształcenie studentów i wychowanie kadry naukowej}

Zajęcia dydaktyczne Pani Profesor prowadzi nieprzerwanie od momentu swojego zatrudnienia na Wydziale Ekonomiczno-Socjologicznym UŁ. Stosownie do własnego rozwoju naukowego i zapotrzebowania Uczelni stopniowo rozszerzała swą ofertę zajęć. Od ćwiczeń (prowadzonych jako asystent), poprzez wykłady, seminaria dyplomowe i magisterskie, do seminariów doktorskich podjętych po uzyskaniu stopnia doktora habilitowanego. Opiekuje się też studentami z indywidualnym tokiem studiów. W Jej ofercie znajdują się również wykłady i seminaria w języku francuskim dla studentów polskich i zagranicznych.

Praca dydaktyczna Prof. Aleksandry Jewtuchowicz nie ogranicza się tylko do działalności w Uniwersytecie Łódzkim. Wykładała również na innych uczelniach w kraju, m.in. na Podyplomowym Studium Planowania Przestrzennego Wydziału Architektury Politechniki Warszawskiej (1993-1995), na Uniwersytecie Mikołaja Kopernika w Toruniu (1998-2006), Wyższej Szkole Humanistyczno-Ekonomicznej w Pabianicach (2002-2010) i innych. Istotnymi w Jej działalności dydaktycznej sa wykłady prowadzone na uczelniach zagranicznych. Pierwsze doświadczenia pod tym względem uzyskała w latach 1991-1993 we współpracy z Międzynarodową Szkołą Konsultantów (L'Ecole des Consultants) w Angers we Francji.

Znaczące miejsce w Jej działalności dydaktycznej zajmuje współpraca z Uniwersytetem w Montpellier III, w którym od 1993 r. systematycznie prowadzi wykłady i seminaria ze studentami tej uczelni. Uniwersytet ten systematycznie zaprasza Ja w charakterze profesora wizytujacego (professeur invité) oraz w ramach programu Socrates i bezpośredniej współpracy. Tematyka wykładów pokrywa się z Jej specjalizacja naukowa i dotyczy ekonomiki miast i regionów, terytorium i rozwoju terytorialnego, funkcjonowania samorządów terytorialnych, polityki regionalnej, w tym polityki Unii Europejskiej, itp.

Działalność dydaktyczna i naukowa na innych uczelniach nie zmniejsza w żaden sposób Jej zaangażowania w pracę w macierzystej jednostce. Zawsze była i jest do dyspozycji pracowników i studentów. W 1998 z Jej inicjatywy i przy znaczaccym zaangażowaniu uruchomiony 
został kierunek „Gospodarka przestrzenna”, który w tym czasie, na studiach ekonomicznych był zupełnie nowatorskim, interdyscyplinarnym kierunkiem kształcenia i od początku cieszył się duża popularnością. Ponadto, w ramach tego kierunku prowadzi specjalność „Zarządzanie miastem i regionem". Będacc koordynatorem i opiekunem kierunku i specjalności (a także z tytułu pełnienia funkcji dyrektora Instytutu Gospodarki Przestrzennej) odpowiada za cały proces dydaktyczny, tzn. plany i programy nauczania ze wszystkich przedmiotów na wszystkich typach studiów.

Dobrze układająca się współpraca zakładów i katedr zorientowanych na badania przestrzenne i rosnąca liczba studentów kierunku spowodowała, że w 2003 r. podjęto decyzję o utworzenie jednostki organizacyjnej mogacej koordynować proces dydaktyczny. W ten sposób w grudniu 2004 r. powołany został Instytut Gospodarki Przestrzennej składajacy się z 5 Katedr: Gospodarki Regionalnej i Środowiska kierowanej przez prof. dr hab. Aleksandre Jewtuchowicz, Gospodarki Samorządu Terytorialnego kierowanej przez prof. dr hab. Eugeniusza Wojciechowskiego, Polityki Ekonomicznej kierowanej przez prof. dr hab. Elżbietę Kryńska, Inwestycji i Nieruchomości kierowanej przez prof. dr hab. Ewę Kucharska-Stasiak oraz Ekonometrii Przestrzennej kierowanej przez prof. dr hab. Bogdana Sucheckiego (aktualnie przez prof. dr hab. Jadwige Suchecka). Dyrektorem Instytutu zostaje prof. Aleksandra Jewtuchowicz i funkcję tę pełni do dzisiaj.

Doświadczenia dydaktyczne i wiedza Pani Profesor powoduja, że zarówno studenci jak i doktoranci wybieraja Ja na promotora swoich prac i dysertacji. Ogółem była opiekunem naukowym ponad 250 absolwentów (na wszystkich typach studiów). Wypromowała 11 doktorów nauk ekonomicznych, aktualnie pod jej kierunkiem otwarte sa 4 kolejne przewody. Warte podkreślenia jest, że trzon kierowanej przez nią Katedry Gospodarki Regionalnej i Środowiska stanowia osoby, które napisały swoje dysertacje pod jej kierunkiem a w ubiegłym roku, jedna z Jej pierwszych doktorantek, Aleksandra Nowakowska, obroniła z sukcesem rozprawę habilitacyjną.

Pani Profesor jest ponadto autorka trzydziestu recenzji dysertacji doktorskich, sześciu recenzji w przewodach habilitacyjnych (w tym cztery wydawnicze), dwóch recenzji tzw. „książek profesorskich”, licznych recenzji projektów badawczych i wykonanych na ich podstawie opracowań, wielu recenzji wydawniczych książek i artykułów oraz kilkudziesięciu recenzji referatów w obcych językach (francuskim i angielskim) kwalifikowanych na konferencje zagraniczne, licznych recenzji prac magisterskich i licencjackich. Od $1990 \mathrm{r}$. była stałym recenzentem KBN (aktualnie NCN), dla którego systematycznie wykonuje opinie 
naukowe projektów przygotowywanych przez różne grupy badawcze. Za działalność naukową i dydaktyczną uzyskiwała nagrody rektorskie oraz odznaczenia, a przede wszystkim Srebrny Krzyż Zasługi, Medal Złoty za Długoletnią Służbę oraz Medal Komisji Edukacji Narodowej.

Działalność i zaangażowanie w pracy naukowej i dydaktycznej Pani Profesor Aleksandry Jewtuchowicz zaowocowały zbudowaniem dużego, młodego i interdyscyplinarnego zespołu, złożonego głównie z Jej byłych doktorantów. Dorobek naukowy oraz doświadczenie Profesor Aleksandry Jewtuchowicz były dla wielu $\mathrm{z}$ nas inspiracja do podejmowania nowych tematów badawczych, a Jej życzliwość dużym wsparciem w pogłębianiu zainteresowań naukowych.

Dla nas - osób mających zaszczyt i przywilej pracy i codziennego kontaktu z Pania Profesor - naturalnym wydaje się odwołanie do Jej cech charakteru, które sprawiają, że Pani Profesor jest dla nas nie tylko wybitnym akademikiem i przewodnikiem w drodze rozwoju naukowego, ale przede wszystkim - wspaniałym Człowiekiem. Jej życzliwość, otwartość i serdeczność w kontaktach z drugim człowiekiem, właściwy dystans do świata i wyjątkowe poczucie humoru powoduja, że Pani Profesor jest dla nas osoba wyjątkowa - mądrym Nauczycielem, i wreszcie - nieocenioną Koleżanką i Przyjaciółką.

Aleksandra Nowakowska z Zespołem Pracowników Katedry Gospodarki Regionalnej i Środowiska 